\title{
Penilaian Kinerja Guru Mengenai Profesionalisme Guru Di Smp Negeri 2 Pangaribuan Kabupaten Tapanuli Utara Tahun 2020
}

Tiamsa Gultom

Smp Negeri 2 Pangaribuan

Corresponding Author $\otimes$ tiamsagultom@gmail.com

\author{
ARTICLE INFO \\ Article history: \\ Received \\ 20 Oktober 2020 \\ Revised \\ 25 Oktober 2020 \\ Accepted \\ 10 November 2020
}

\section{Kata Kunci}

How to cite

\section{ABSTRACT}

Penelitian ini membahas tentang penilaian kinerja guru untuk mengukur profesionalisme guru di SMP Negeri 2 Pangaribuan. Adapun kajiannya dilatar belakangi oleh tuntutan seorang guru yang profesioanl dalam semua mata pelajar di semua jenjang pendidikan. Terlebih dengan peraturan UUD Guru dan Dosen, serta adanya sertifikasi pendidik. Maka untuk dapat mengukur itu dilakukan penilaian kinerja guru yang meliputi empat komponen dasar, yaitu pedagogik, kepribadian, sosial, dan profesional. Penelitian ini dimaksudkan untuk menjawab permasalahan: (1) Bagaimana penilaian kinerja guru di SMP Negeri 2 Pangaribuan?, (2) Bagaimana upaya yang harus dilakukan kepala sekolah dalam meningkatkan profesionalisme guru di SMP Negeri 2 Pangaribuan?. Penelitian ini termasuk jenis penelitian lapangan (field research). Oleh karena itu objek yang diteliti di sekolah yang sekiranya mampu memberikan informasi tentang kajian penelitian. Agar penelitian ini dapat tercapai dengan baik, maka dalam metode penelitiannya diperlukan langkah-langkah sistematis berencana, dan sesuai dengan kaidah keilmuan. Selain itu penelitian kualitatif juga dilakukan secara intensif, berpartisipasi untuk mencatat segala data kemudian melakukan analisis terhadap data yang didapat selama penelitian. Kajian ini menunjukan bahwa: (1).Kinerja guru dapat diukur dengan dilakukan penilaian kinerja guru yang merupakan suatu kegiatan membina dan mengembangkan guru profesional yang dilakukan dari guru, oleh guru, untuk guru. Kepala sekolah menilai pelaksanaan pembelajaran meliputi pra pembelajaran (pengecekan kesiapan kelas dan apersepsi), kegiatan inti (penguasaan materi, strategi pembelajaran, pemanfaatan media/sumber, penilaian proses dan hasil belajar, penggunaan bahasa), dan menutup (refleksi, rangkuman dan tindak lanjut) (2) Upaya kepala sekolah dalam meningkatkan profesionalisme guru dengan memberikan (a) pembinaan kepada para guru dalam menyusun rencana pembelajaran, (b) memantau para guru dalam melaksanakan pembelajaran, (c) mengawasi jalannya programprogram kegiatan pendidikan., (d) mengecek keadaan dan keutuhan fasilitas sekolah sebagai penunjang prestasi peserta didik, (e) mengevaluasi lewat briefing dan rapat program pendidikan

\begin{tabular}{l} 
Briefing, Pendidik, Pembelajaran \\
\hline Gultom tiamsa, (2020). Penilaian Kinerja Guru Mengenai \\
Profesionalisme Guru Di Smp Negeri 2 Pangaribuan Kabupaten Tapanuli \\
Utara Tahun 2020. Jurnal Journal of Education and Teaching Learning \\
(JETL).
\end{tabular}




\section{PENDAHULUAN}

Guru adalah seorang tenaga pendidik yang profesional sehingga mempunyai tugas, fungsi, serta peran penting dalam mencerdaskan kehidupan suatu bangsa. Adapun persyaratan untuk bisa disebut sebagai tenaga pendidik profesional antara lain mempunyai keterampilan yang berlandaskan konsep dan teori ilmu pengetahuan, yang berlandaskan filosofis, psikologis, dan sosiologis. Seorang guru juga harus memiliki kompetensi yang memadai, adapun kompetensi itu mencakup kompetensi profesional, pedagogik, sosial, dan juga personal. Dalam praktiknya, kompetensi tersebut akan membentuk kepribadian guru yang bisa menentukan kualitas pembelajaran serta pembimbingan peserta didik.

Seperti juga yang tercantum dalam Peraturan Menteri Negara Pendayagunaan Aparatur Negara dan Reformasi Birokrasi Nomor 16 Tahun 2009, Penilaian Kinerja Guru adalah penilaian dari tiap butir kegiatan dan tugas utama guru dalam rangka pembinaan karir, kepangkatan, dan jabatannya. Pelaksanaan tugas utama guru tidak dapat dipisahkan dari kemampuan seorang guru dalam penguasaan dan penerapan pengetahuan serta keterampilan, sebagai kompetensi yang dibutuhkan sesuai amanat Peraturan Menteri Pendidikan Nasional Nomor 16 Tahun 2007 tentang Standar Kualifikasi Akademik dan Kompetensi Guru.

Sebuah jabatan profesional perlu dikembangkan melalui jenjang pendidikan tertentu, yang mempersiapkannya dengan bekal pengetahuan, keterampilan, serta sesuai dengan bidang profesinya. Hal ini bertujuan agar lulusan lembaga pendidikan tidak hanya dinilai oleh lembaga tersebut, tetapi juga oleh masyarakat dan pemakai lulusan. Namun sampai saat ini masih ada sebagian masyarakat yang meragukan profesi guru, terutama karena beberapa alasan. Guru merupakan karir terbuka terbuka sehingga siapapaun bisa menjadi guru, asalkan telah lulus jenjang pendidikan tertentu, yang dalam undang-undang dan peraturan pemerintah sekarang ini ditetapkan minimal S1 atau D-4. Bukti-bukti di lapangan menunjukkan bahwa pendidikan dapat saja berhasil walaupun gurunya tidak pernah belajar ilmu kependidikan, sebaliknya guru lulusan ilmu pendidikan tidak dapat menjamin keberhasilan tersebut. Hal ini menunjukan bahwa hasil dan manfaat pendidikan yang sebenarnya tidak dapat diamati dan ditunjukkan dalam waktu yang relatif singkat seperti profesi seorang kedokteran atau teknologi, tetapi baru tampak setelah beberapa tahun lulusannya mengabdikan diri di masyarakat, itupun sudah di pengaruhi oleh lingkungannya.

Seorang guru juga harus mempunyai keahlian khusus sesuai dengan bidang profesi yang ditekuninya, serta senantiasa berusaha untuk 
meningkatkan perkembangan dan kebutuhan di lingkungan masyarakat. Contohnya, seorang guru harus bisa mengikuti perkembangan suatu ilmu pengetahuan, serta perkembangan teknologi yang berkembang dimasa kini. Sehingga dapat memperhatikan adanya perkembangan di dalam dunia usaha atau juga dalam perkembangan dunia industri.

Seperti yang tercantum dalam UU No.14 Tahun 2005 Bab IV Pasal 20 yang berisi tentang tugas Guru dan Dosen dalam melaksanakan tugas keprofesioanalnya, guru berkewajiban merencanakan pembelajaran, melaksanakan proses pembelajaran, serta menilai dan evaluasi hasil pembelajaran Kinerja guru merupakan kemampuan kerja yang dicapai oleh seorang guru dalam melaksanakan tugas sebagai seorang pengajar yang professional. Kinerja yang dimaksud adalah kinerja dalam proses pembelajaran yang meliputi perencanaan, pelaksanaan dan evaluasi pembelajaran. Dalam hal ini Penilaian Kinerja Guru sangat berpengaruh penting dalam dunia pendidikan. Dengan adanya Penilaian ini diharapkan guru sebagai tenaga pendidik harus mampu menjalankan fungsi serta tugasnya.

Adapun secara umum tugas dan fungsi seorang guru antara lain. Mendidik, mengajar, membimbing dan melatih. Fungsi sebagi pendidik ialah mengembangkan kompetensi/kemampuan dasar peserta didik, mengembangkan kepribadian peserta didik, memberikan keteladanan serta menciptakan suasanan pendidikan yang kondusif. Sebagai pengajar fungsinya merencanakan pembelajaran, melaksanakan pembelajaran yang mendidik, menilai proses dan hasil pembelajaran. Adapun fungsi sebagai pembimbing yaitu mendorong berkembangnya perilaku positif dalam pembelajaran, serta membimbing peserta didik memecahkan masalah dalam pembelajaran. Sebagai pelatih, melatih keterampilan yang diperlukan dalam pembelajaran, membiasakan peserta didik berperilaku positif dalam pembelajaran. Tugas selanjutnya membantu pengelolaan dan pengembangan program sekolaph, Adapun fungsinya sebagai pengembang program yaitu membantu mengembangkan program pendidikan sekolah dan hubungan kerjasama intra sekolah. Serta fungsi sebagai pengelola program yaitu membantu secara aktif dalam menjalin hubungan dan kerja sama antar sekolah dan masyarakat. Yang terakhir tugas guru ialah mengembangkan profesional, yaitu sebagai tenaga profesional yang dimaksudkan adalah melakukan upaya untuk meningktkn kemampuan profesional. Dosen Serta adanya undang-undang yang mengatur tentang Guru dan Dosen merupakan tetapan suatu politik bahwa pendidik adalah pekerja profesional, yang berhak mendapatkan hakhak sekaligus kewajiban profesional. Dalam undang- undang guru dan dosen 
di jelaskan sebagai berikut, guru wajib memiliki kualifikasi akademik dan kompetensi pendidik sebagai agen pembelajaran. Kualifikasi akademik diperoleh melalui pendidikan tinggi program sarjana (S-1) atau program diploma empat (D-IV) yang sesuai dengan tugasnya sebagi guru untuk guru dan (S-2) untuk dosen. Dalam hal ini, seorang guru memang memerlukan adanya suatu penilaian kinerjanya, guna menunjang suatu profesionalisme dan personalnya. Yang di maksud dengan profesionalisme itu sendiri adalah menunjuk kepada komitmen para anggota suatu profesi yang dimaksud disini adalah seorang tenaga pendidik atau guru untuk meningkatkan kemampuan profesionalnya dan terus menerus mengembangkan strategi-strategi yang digunakan dalam melaksanakan pekerjaan yang sesuai denga profesinya. Fenomena yang ada sekarang ini, demi mengejar adanya tuntutan mengajar 24 jam, guru berlomba-lomba untuk mengejar kuota tersebut tanpa melihat situasi serta kondisi dari peserta didiknya.

Ini sungguh tidak seuai dengan profesionalismenya. Sehingga dengan mengangkat judul "Penilaian Kinerja Guru mengenai Profesionalisme Guru" diharapkan dapat membantu para tenaga pendidik untuk lebih memperhatikan kompetensi pedagogik, kompetensi kepribadian, adapun kompetensi sosial, sera dalam kompetensi professional. Berkaitan dengan tugas dan kompetensi guru, terdapat berbagai pendapat dan berbagai rumusan. Sebagai pegangan dapat dirujuk rumusan nasional yang telah disepakati dan tercantum dalam Undang-Undang Sisdiknas (pasal 39) adalah sebagai berikut. Pendidik merupakan tenaga profesional yang bertugas merencanakan dan melaksanakan kegiatan pembelajaran, menilai hasil pembelajaran, melakukan pembimbingan dan pelatihan, serta melakukan peneliyian dan pengabdian kepada masyarakat, terutama bagi pendidik pada perguruan tinggi.

Dengan berbagai ulasan serta pernayataan yang diterangkan diatas, bahwa Pengembangan Kinerja Guru memang sangat berpengaruh terhadap profesioanlitas tenaga pendidik. Pengembangan keprofesian guru sangat menentukan mutu suatu pendidikan. Dalam hal ini profesionalitas harus dikembangkan. Dengan adanya Pengembangan Kinerja Guru ini, diharapkan dapat meningkatkan profesionalitas sebagai tenaga pendidik. Sehingga menghasilkan lulusan yang memang berakhal mulia, kompeten dalam bidangnya dan menjadi masyarakat yang berguna bagi nusa bangsa dan Negara, agama serta tuanya. Dengan berbagai pertimbangan yang telah ada, sehingga penulis mengetahui dan memahami adakah "Penilaian Kinerja Guru Mengenai Profesionalisme Guru Di SMP Negeri 2 Pangaribuan”. 


\section{METODOLOGI PENELITIAN}

Penelitian ini merupakan penelitian kualitatif deskritif yaitu jenis penelitian data yang objektif dan alami lapangan. Menurut Bog dan Taylor, metode kualitatif adalah prosedur penelitian yang menghasilkan data deskriptif berupa kata-kata tertulis atau lisan dari orang-orang dan perilaku yang diamati. Pendekatan penelitian kualitatif adalah proses penelitian yang menghasilkan data deskriptif berupa kata-kata tertulis atau lisan dari orangorang dan perilaku yang dapat diamati. oleh karena itu, penelitian ini menggunakan metode deskriptif. Jadi jenis penelitian ini memahami pendekatan kualitatif karena melalui pendekatan tersebut lebih tepat untuk mengindentifikasi penilaian kinerja guru dalam meningkatkan profesionalisme guru di SMP Negeri 2 Pangaribuan. Adapun teknik pengumpulan data yang digunakan seperti observasi, interview dan dokumentasi. Untuk pengujian keabsahan data dilakukan dengan triangulasi data

\section{HASIL DAN PEMBAHASAN}

\section{Deskriptif Penilaian Kinerja Guru SMP Negeri 2 Pangaribuan}

Kompetensi berasal dari bahasa inggris yaitu competency yang berarti kecakapan, kemampuan, dan wewenang. Kompetensi juga diartikan sebagai pengetahuan, keterampilan, dan nilai-nilai dasar yang direfleksikan dalam kebiasaan berpikir dan bertindak.arti lain dari kompetensi adalah spesifikasi dari pengetahuan, ketrampilan, dan sikap yang dimiliki seseorang serta penerapannyadidalam pekerjaan, sesuai standar kinerja yang di butuhkan oleh lapangan. Dari pengertian tersebut standar kompetensi guru adalah suatu pernyataan tentang kriteria yang di persyaratkan, ditetapkandan disepakati bersamadalam bentuk penguasaan pengetahuan, ketrampilan dan sikap bagi seorang tenaga kependidikan sehingga layak di sebut kompeten.

Berdasarkan uraian diatas direktorat jendral pendidikan dasar dan menengah, departemen pendidikan nasional menerapkan standar kompetensi guru yang berhubungan dengan: (1). Komponen kompetensi pengelolaan pembelajaran dan wawasan kependidikan. (2). Komponen kompetensi Akademik sesuai materi pembelajaran. (3). Pengembanagan profesi . pada pasal 8 UU guru dan dosen, secara eksplisit menyebutkan bahwa guru wajib memiliki kualifikasi akademik, kompetensi, sertifikat pendidik, sehat jasmani dan rohani, serta memiliki kemampuan untuk mewujudkan tujuan pendidikan nasional. khusus tentang kompetensi ini di jelaskan pada undangundang guru dan dosen pasal 10 ayat 1 yang menyebutkan kompetensi guru sebagaiman disebutkan pada pasal 8 meliputi kompetensi pedagogik, 
kompetensi kepribadian, kompetensi sosial, dan kompetensi profesional yang di peroleh melalui pendidikan profesi.

Dalam parktiknya, kompetensi tersebut akan membentuk kepribadian guru yang sangat menentukan kualitas pembelajaran dan pembimbingan peserta didik, serta mendorong terlaksananya seluruh tugas tambahan secar profesional. Kompetensi guru yang utuh dan menyeluruh mencakup empat kompetensi yaitu:

1. Kompetensi pedagogik menurut Depdiknas (2008:4) adalah "kemampuan yang harus dimiliki guru berkenaan dengan karakteristik siswa dilihat dari berbagai aspek seperti moral, emosional, dan intelektual" yaitu mengenal karakteristik peserta didik, menguasai teori belajar dan prinsip- prinsip pembelajaran yang mendidik.

2. Kompetensi profesional menurut Depdiknas (2008:6) yaitu "kemampuan yang harus dimiliki guru dalam perencanaan dan pelaksanaan proses pembelajaran" Guru mempunyai tugas untuk mengarahkan kegiatan belajar siswa untuk mencapai tujuan pembelajaran, untuk itu guru dituntut mampu menyampaikan pelajaran. Mencakup penguasaan materi, struktur, konsep dan pola pikir keilmuan yang mendukung mata pelajaran yang diampu dan mengembangkan keprofesionalan melalui tindakan yang relative.

3. Kompetensi sosial menurut Depdiknas (2008) meliputi "kemampuan guru dalam berkomunikasi, bekerja sama, bergaul, simpatik, dan mempunyai jiwa yang menyenangkan". Yaitu guru mampu beradaptasi dengan lingkungan proses pembelajaran di sekolah baik dengan sesama tenaga pendidik, orang tua peserta didik masyarakat dan industry yang bekerja sama. Yaitu bersikap inklusif, bertnidak obyektif, serta tidak deskriminatif, komunikasi dengan sesama guru, tenaga kependidikan, orang tua, peserta didik dan masyarakat.

4. Kompetensi kepribadian menurut sanjaya (2007:18) "guru sering dianggap sebagai sosok yang memiliki kepribadian ideal.karena itu pribadi guru sering dianggap sebagai model atau panutan (yang di gugu dan ditiru)". Sebagai model yang harus memiliki kepribadian yang mencerminkan sosok yang dapat dijadikan panutan oleh peserta didik dan masyarakat lainnya. Yaitu bertindak sesuai dengan norma agama, hukum, sosial dan kebudayaan nasional, menunjukkan pribadi yang dewasa dan teladan, Etos kerja, tanggung jawab yang tinggi, serta rasa bangga menjadi guru. 


\section{Deskriptif Upaya Kepala Sekolah dalam Meningkatkan Profesionalisme Guru Di SMP Negeri 2 Pangaribuan}

Pada setiap manusisa terdapat bakat dan potensi yang berbeda-beda. Mengingat hal terssebut sangat penting dalam penilaian kinerja guru, maka kepala sekolah menilai kinerja guru. Agar dapat mengetahui potensi guru dan dapat member pengarahan kepada semua staf dan guru supaya bisa meningkatkan potensi.

1) Kegiatan pengembangan diri

Penilaian kegiatan pengembangan diri bersifat kualitatif. Potensi, ekspresi, perilaku, dan kondisi psikologis merupakan portofolio yang digunakan untuk penilaian. Agar tercapainya penilaian kinerja guru mengenai profesionalisme guru dalam mengajar maka Kepala SMP Negeri 2 Pangaribuan memfasilitasi kegiatan pengembangan diri.

2) Program pembiasaan

Kepala SMP Negeri 2 Pangaribuan mengintruksikan kepada para guru agar sebelum melakukan kegiatan pembelajaran harus melakukan kegiatan yang bersifat pembinaan karakter peserta didik yang dilakukan secara rutin, spontan, dan keteladanan. Pembiasaan tersebut seperti melakukan doa bersama-sama dengan siswa-siswinya, menanyakan tentang materi sebelumnya kepada siswa dan menanyakan kepada siswa barangkali ada yang masih belum paham terhadap materi yang sudah diberikan. Pembiasaan ini dilaksanakan sepanjang waktu belajar di SMP Negeri 2 Pangaribuan, seluruh guru ditugaskan untuk membina program pembiasaan yang ditetapkan oleh SMP Negeri 2 Pangaribuan·

3) Pengoptimalan kegiatan pembelajaran.

SMP Negeri 2 Pangaribuan dituntut untuk lebih mandiri untuk mengatur rumah tangganya, dalam masalah ini lewat kepala sekolah yang kreatif dan inovatif SMP Negeri 2 Pangaribuan mempunyai langkah-langkah ynag di terapkan kepada guru dalam mengoptimalkan kinerjanya supaya penilaian kinerja guru mengenai profesionalisme dengan kegiatan pembelajaran siswa agar menjadikan siswa yang berprestasi diantarannya adalah

4) Pengembangan kurikulum.

Kepala SMP Negeri 2 Pangaribuan melakukan pembaharuan terhadap kurikulum sesuai dengan perubahaan-perubahan yang ditetapkan, mengupayakan pengembangan kurikulum secara maksimal dapat disesuaikan dengan kondisi dan situasi berada. Disamping itu diupayakan terciptanya pendidikan dan pengajaran yang bermutu dengan harapan dapat 
menghasilkan lulusan yang siap menguasai IPTEK (Ilmu Pengetahuan dan Teknologi).

5) Pengembangan Proses Belajar Mengajar (PBM).

PBM yang ada di SMP Negeri 2 Pangaribuan adalah sebagaimana PBM di sekolah-sekolah lain yang menerapkan berbagai macam metode pembelajaran seperti ceramah, diskusi, Tanya jawab, dan lain-lain.

Namun untuk meningkatkan PBM yang lebih bermutu dari tahun ketahun guna penilaian kinerja guru mengenai profesionalisme guru, maka SMP Negeri 2 Pangaribuan melakukan hal sebagai berikut :

a. Pengadaan pelatihan guru tentang "Pembelajaran yang Efektif dan Efisien" yang disampaikan oleh kepala sekolah langsung kepada bawahnnya.

b. Mengadakan Achivement Motivation Training (AMT) untuk membangkitkan semangat siswa dalam belajar yang dilaksanakan oleh Wakil Kepala Sekolah Bidang Kesiswaan sekali pada waktu awal tahun bagi kelas satu.

c. Audiensi guru dengan pengelola yang dilaksanakan oleh para guru dan kepala sekolah secara kondisional agar lebih memahami arti proses belajar mengajar.

6) Pengembangan SDM sekolah

Pengembangan SDM dalam meningkatkan profesionalisme guru sangat perlu digalahkan di SMP Negeri 2 Pangaribuan. Hal ini mengingat bahwa prestasi tidak dapat dicapai dengan baik melainkan ditopang dengan pemberdayaan kualitas SDM sekolah sebagai motor pengerak jalannya proses pendidikan, untuk mengembangkan SDM maka Kepala SMP Negeri 2 Pangaribuan melakukan:

a. mengadakan pertemuan-pertemuan atau rapat baik rapat kerja, rapat pimpinan, rapat istimewa, rapat guru, rapat bidang, rapat gabungan, rapat koordinasi dan rapat dinas. Semuanya dalam rangka membahas kinerja guru secara personil sekolah yang dilaksanakan mingguan, bulanan, tahunan bahkan sewaktu-waktu.

b. mengirimkan delegasi sekolah yang diikuti oleh para guru dan tenaga kependidikan ke berbagai institusi pendidikan wilayah Kecamatan Pangaribuan yang dilaksanakan 6 kali dalam setahun dalam rangka peningkatan kualitas dan pengembangan SDM .

c. Mengadakan seminar, workshop dan pelatihan di sekolah untuk meningkatkan profesionalisme guru yang dilaksanakan oleh kepanitiaan guru sebanyak 2 kali dalam setahun yaitu setiap semester genap dan ganjil. 
d. Menghadiri seminar, workshop dan pelatihan di luar sekolah khususnya tentang usaha memperoleh masukan-masukan kebijakan yang dapat digunakan sebagai rujukan dan acuan dalam upaya meningkatkan profesionalisme guru dalam pembangunan pendidikan, seperti “ Seminar Peningkatan Profesional dan Kesejahteraan Guru".

7) Pengembangan fasilitas sekolah

Pengembangan fasilitas merupakan agenda rutin sekolah untuk melengkapi berbagai keperluan pendidikan agar kinerja guru dalam meningkatkan profesionaliotas pembelajaran dapat tercapai. Dalam hal tersebut Kepala SMP Negeri 2 Pangaribuan selalu mengecek perlengkapan peralatan-peralatan kelas dan alat-alat bantu pembelajaran apabila terjadi kerusakan atau kehilangan maka kepala sekolah segera mengganti atau memperbaiki kalo bisa diperbaikinya. Selain itu kepala sekolah juga mengecek kebersihan lingkungan sekolah. Karena kegiatan tersebut merupakan bagian dari penunjang prestasi didik dan juga pengawasan.

Kepala SMP Negeri 2 Pangaribuan menginstruksikan kepada bagian pegawai perpustakaan untuk dapat menyediakan buku-buku yang menunjang pelajaran dari berbagai penerbit seperti buk-buku pelajaran agama, pelajaran umum, dan muatan lokal yang dilakukan secara rutin dengan tujuan untuk menambah pengetahuan para siswa dan guru selalu mengembangkan fasilitas-fasilitas yang ada di sekolah.

8) Peningkatan kedisiplinan

Kepala SMP Negeri 2 Pangaribuan dalam meningkatkan kedisiplinan melalui penerapan yang efektif bagi masing-masing guru, karyawan, dan siswa. Hal ini dibuktikan dengan cara menerapkan kepada semua warga sekolah diharapkan mengikuti doa bersama, guru mempunyai tugas mengajar pada jam pertama harus datang dan masuk kelas tepat waktu, apabila ada guru yang sakit atau berhalangan masuk maka harus ada keterangannya, ketika guru terlambat masuk kelas karena ada kepentingan mendadak sebelumnya guru tersebut memberi tahu kepada guru piket apabila guru tersebut tidak ada kabar sama sekali maka kepala sekolah memberikan sanksi kepada guru tersebut, seperti teguran, apabila teguran tersebut tidak dapat merubah perilakunya maka akan diberikan surat peringatan, dll.

\section{Analisis penilaian kinerja guru di SMP Negeri 2 Pangaribuan}

Secara umum penilaian kinerja guru ada dua fungsi utama seperti yang di kemukakan kemendiknas tahun 2010 yaitu

a. Untuk menilai kemampuan guru dalam menerapkan kompetensi dan ketrampilan yang di perlukan dalam pembelajaran, pembimbingan, atau pelaksanaan tugas tambahan yang relevan dengan fungsi sekolah. 
b. Untuk menghitung angka kredit yang di peroleh guru atas kinerja pembelajaran, pembimbingan, atau pelaksana tugas tambahan yang relevan dengan fungsi sekolah yang di lakukan pada tahun tersebut. Oleh karena itu, kegitan penilaian kinerja dilakukan setiap tahun sebagai bagian dari proses pengembangan karir dan promosi guru untuk kenaikan pangkat dan jabatan fungsional.

Kepala sekolah SMP Negeri 2 Pangaribuan melakukan penilaian kinerja guru mengenai profesionalisme guru melalui beberapa tindakan yaitu dengan membina para guru dalam menyususn rencana pembelajaran, memantau para guru dalam melaksanakan pembelajaran peserta didik. mengawasi jalannya program-program kegiatan peseta didik, mengecek keadaan dan keutuhan fasilitas sekolah sebagai penunjang proses prestasi peserta didik, mengevaluasi lewat briefing dan rapat tentang prestasi peserta didik, Kegiatan pengawasan pada dasarnya membandingkan kondisi yang ada dengan yang seharusnya terjadi. Apabila dalam prosesnya terjadi penyimpangan/ hambatan / penyelewengan segera dilakukan tindak koreksi.

Hambatan yang ditemui saat kepala sekolah SMP Negeri 2 Pangaribuan melakukan pengawasan adalah terdapat guru maupun karyawan yang belum benar-benar memegang komitmennya dalam mendidik siswa seperti banyak guru yang izin tidak mengajar dan pada saat masuk pagi mungkin masih ada yang terlambat, dalam kegiatan disekolah terkadang masih ada guru yang tidak datang dalam kegiatan tersebut untuk melatih atau membina peserta didik.

Setelah penulis melakukan penelitian maka Faktor pendukung dan penghambat dalam penilaian kinerja guru di sekolah SMP Negeri 2 Pangaribuan adalah sebagai berikut.

a. Faktor pendukung peningkatan profesionalisme guru

1. Koordinasi yang baik antara kepala sekolah, guru

2. Kinerja guru lebih efektif dalma pembelajran

3. Guru penilaian pembelajaran oleh kepala sekolah.

4. Tenaga edukatif telah mengikuti kegiatan penyetaraan pendidikan.

5. Guru aktif dalam kegiatan sekolah.

b. Faktor penghambat peningkatan prestasi siswa

1. Minimnya bantuan biaya operasional pendidikan dari pemerintah.

2. Bantuan yang diberikan pemerintah untuk biaya operasional sekolah dianggap kurang memenuhi kebutuhan sekolahan.

3. Perpustakaan sekolah yang belum representatif. 
Kurangnya koleksi-koleksi buku yang dapat menarik siswa untuk mengembangkan potensinya, misalnya buku-buku tentang keagamaan dan lain sebagainya.

\section{Analisis Upaya Kepala sekolah dalam Meningkatkan profesionalisme guru.}

Upaya dapat diartikan sebagai tidak lanjut atau pelaksanaan kegiatan yang didesain untuk mencapai tujuan pendidikan tertentu. Tujuan pendidikan di SMP Negeri 2 Pangaribuan yang utama adalah pembetukan prestasi peserta didik yang beriman, berilmu, berakhlakul karimah, cerdas sesuai dengan tujuan sekolah. Untuk mencapai tujuan tersebut kepala Sekolah menggunakan beberapa upaya dalam ofesionalisme guru terhadap pembentukan prestasi peserta didik.

profesionalistas guru dapat menoreh prestasi yang membanggakan bagi siswa, Hal ini tidak mudah mengingat segala sesuatu yang perlu ditopang oleh kualitas sekolah yang baik disegala hal. Peran Kepala sekolah sangat dibutuhkan dalam mengarahkan personilnya untuk lebih profesional dalam pembelajaran supaya dapat mencetak siswa yang benar-benar berprestasi.

Meskipun siswi SMP Negeri 2 Pangaribuan hanya sedikit, tetapi hal ini dapat dijadikan peluang yang sangat bagus dalam menilai mengawasi, mengarahkan serta mengfokuskan profesionalisme kinerja guru dalam mengoptimalkan prestasi siswi, Kepala sekolah melalui personilnya berusaha membuat suatu formula yang efektif dan prospektif yang sudah teruji keberhasilannya dengan indikator berbagai prestasi yang pernah diraih siswi SMP Negeri 2 Pangaribuan. Upaya ini dapat dioptimalkan melaui tiga sisi yakni:

a. Menumbuhkembangkan bakat dan potensi siswi, berupa:

1) Kegiatan pengembangan diri

Pengembangan diri adalah kegiatan yang bertujuan memberikan kesempatan kepada peserta didik untuk mengembangkan dan mengekspresikan diri sesuai dengan kebutuhan, bakat, minat, setiap peserta didik sesuai dengan kondisi sekolah.

2) Program pembiasaan

Program pembiasaan, mencangkup kegiatan yang bersifat pembinaan karakter peserta didik yang dilakukan secara rutin, spontan, dan keteladanan.

b. Pengoptimalan kegiatan pembelajaran.

1. Pengembangan Kurikulum.

2) Pengembangan Proses Belajar Mengajar (PBM)

3) Pengembangan SDM sekolah

4) Pengembangan Fasilitas sekolah.

5) Peningkatan Kedisiplinan. 


\section{6) Peningkatan Kemampuan Kognitif Siswa}

Berdasarkan data, penilaian kinerja guru mengenai profesionalisme guru yang terjadi di SMP Negeri 2 Pangaribuan adalah penilaian kinerja guru yang adil , dimana penilaian kinerja guru disini cenderung pada melaksanakan tindakan-tindakan yang selalu menyerap aspirasi bawahannya, hal ini terbukti saat rapat kerja SMP Negeri 2 Pangaribuan, dewan guru dilibatkan langsung dalam menyusun program untuk kemajuan pendidikan. Tidak gegabah dalam bersikap dan mengambil keputusan, selalu mengakomodasi seluruh kekuatan yang ada secara objektif, hal ini pun bisa dilihat adanya komunikasi langsung antara guru dengan kepala sekolah baik secara individu maupun kelompok.

Kepala sekolah SMP Negeri 2 Pangaribuan senantiasa memperhatikan kebutuhan bawahan dengan berusaha menciptakan suasana saling percaya dan mempercayai, berusaha menciptakan saling menghargai, simpati adap sikap bawahan, memiliki sifat bersahabat, menumbuhkan peran serta dalam pembuatan keputusan dan kegiatan lain,dengan demikian penilaian kinerja guru akan lebih efektif, dengan mengutamakan pengarahan diri, selain itu tumbuh pula rasa respek dan hormat diri dari bawahan kepada pimpinannya.

Sehingga apa yang menjadi tugas merupakan hasil keputusan bersama dapat dilaksanakan dengan sebaik-baiknya. Dan juga, dengan sikap kepala sekolah SMP Negeri 2 Pangaribuan membuka otonomi terhadap guru yang seluas-luasnya untuk meningkatkan profesionalisme kinerja guru dalam memebentuk prestasi siswa.

Kepala sekolah SMP Negeri 2 Pangaribuan telah menjalankan tugasnya dengan baik yaitu memberikan dorongan kepada guru-guru agar aktif bekerja menurut prosedur dan metode tertentu, agar terbentuknya profesionalisme guru dalam pekerjaanya dan berjalan dengan lancar dengan tercapainya sasaran yaitu terhadap penilaian kinerja guru mengenai profesionalisme guru.

Kepala sekolah merupakan motor penggerak, penentu arah kebijakan sekolah, yang akan menentukan bagaimana tujuan dan pendidikan pada umumnya direalisasikan. Sehubungan dengan penilaian kinerja guru, kepala sekolah dituntut untuk senantiasa meningkatkan kinerja. Dengan demikian peningkatan kinerja dapat mempengaruhi peningkatan prestasi siswa sebagai bagian dari tujuan pendidikan dapat tercapai.

Kinerja kepemimpinan kepala sekolah dalam kaitannya dengan penilaian kinerja guru mengenai profesionalisme adalah segala upaya yang dilakukan dan hasil yang dapat dicapai oleh kepala sekolah dalam mengimplementasikan 
manajemen sumber daya pengajaran disekolahnya dalam mewujudkan tujuan pendidikan.

Kepala sekolah mempunyai kedudukan dan fungsi untuk mengarahkan dan mendorong bawahannya agar tugas dan kegiatan disekolah dapat berjalan dengan baik, efektif dan efisien. Sebagai manajer dialah yang membuat perencanaan, mengatur pelaksanaan, mengendalikan dan mengawasi pelaksanaan tugas-tugas, serta menyusun laporan pelaksanaan kegiatan dari kepala sekolah tersebut. Namun demikian, dilingkungan sekolah juga terdapat tuntutan agar kepala sekolah juga mampu untuk berkomunikasi serta mampu memobilisasi partisipasi masyarakat

Supaya hal-hal tersebut diatas dapat terlaksana, seorang kepala sekolah harus memiliki tiga macam ketrampilan. Pertama, ketrampilan organisasi. Wujud nyata dari ketrampilan ini adalah bagaimana kepala sekolah mampu merumuskan visi dan misi sekolah yang selanjutnya dijabarkan dalam sebuah program pendidikan yang pelaksanaannya disusun sedemikian rupa dalam sebuah kerangka organisasi yang tersusun dalam sebuah program pendidikan yang rapi dan sistimatis. Kedua, ketrampilan manusiawi, yaitu ketrampilan untuk bekerjasama, memotivasi dan memimpin. Dan yang ketiga ketrampilan teknik, yaitu ketrampilan dalam menggunakan pengetahuan, metode, teknik, serta perlengkapan untuk menyelesaikan tugas-tugas tertentu.

Jabatan kepala sekolah bukan merupakan jabatan struktural maupun jabatan fungsional, melainkan jabatan tambahan yang diberikan oleh guruguru sekolah yang memiliki kualifikasi tertentu dan terpilih oleh mekanisme pemilihan yang ditentukan. Dalam kasus kepemimpinan sekolah SMP Negeri 2 Pangaribuan. Tercatat sebagai kepala sekolah Tiamsa Gultom,S.Pd. Selama masa jabatannya beliau mempunyai prestasi yang cukup membanggakan pihak sekolah dan juga adanya perkembangan yang cukup signifikan dalam penilaian kinerja guru mengenai profesionalisme guru.

\section{KESIMPULAN}

Penilaian kinerja guru di SMP Negeri 2 Pangaribuan merupakan suatu kegiatan membina dan mengembangkan guru profesional yang dilakukan dari guru, oleh guru, untuk guru. Secara sederhana dapat dikemukakan bahwa kinerja adalah unjuk kerja seseorang yang ditunjukkan dalam penampilan, perbuatan, dan prestasi kerjanya sebagai akumulasi dari pengetahuan, keterampilan, nilai dan sikap yang telah dimilikinya. Salah satu tujuan utama penilaian kinerja guru adalah untuk mengetahui kompetensi guru, untuk mengetahui kompetensi guru ini penilaian kinerja guru dilakukan oleh kepala sekolah. Kepala sekolah menilai kinerja guru dalam pelaksanaan 
pembelajaran meliputi pra pembelajaran (pengecekan kesiapan kelas dan apersepsi), kegiatan inti (penguasaan materi, strategi pembelajaran, pemanfaatan media/sumber, penilaian proses dan hasil belajar, penggunaan bahasa), dan menutup (refleksi, rangkuman dan tindak lanjut) Penilaian oleh kepala sekolah ini dilakukan karena kepala sekolah bertugas untuk melakukan penilaian dan mengambil keputusan yang berhubungan dengan kinerja guru. Kinerja guru dapat ditunjukkan oleh: kemampuan dalam menyusun rencana pelaksanaan pembelajaran, menerapkan strategi pembelajaran, evaluasi, menciptakan lingkungan budaya belajar, pengembangan profesi dan komunikasi. Adapun Upaya Kepala Sekolah SMP Negeri 2 Pangaribuan menegnai peningkatan profesionalisme guru yang telah dilakukan melalui :

a. Pembinaan kepada para guru dalam menyusun rencana pembelajaran

b. Memantau para guru dalam melaksanakan pembelajaran.

c. Mengawasi jalannya program-program kegiatan pendidikan.

d. Mengecek keadaan dan keutuhan fasilitas sekolah sebagai penunjang prestasi peserta didik.

e. Mengevaluasi lewat briefing dan rapat program pendidikan

Dalam upaya peningkatan profesioanlisme guru tersebut dapat diperoleh manfaat:

a. Guru merasa terbantu dalam melaksanakan tugasnya.

b. Menciptakan suasana yang harmonis antara Kepala Sekolah dengan guru-guru, karyawan.

c. Meningkatkan kinerja guru di Sekolah.

d. Mendorong terwujudnya visi Sekolah.

\section{DAFTAR PUSTAKA}

Ardial, Paradigma dan Model Penelitian Komunikasi, Jakarta : Bumi Aksara, 2014.

Arikunto, Suharsimi, Prosedur Penelitian Pendekatan suatu Praktik, Jakarta : Rineka Cipta, 2006.

Depdikbud, Kamus Besar Bahasa Indonesia, Jakarta : Balai Pustaka, 2002.

Dharma, Agus, Manajemen Supervisi: Petunjuk Praktis Bagi Supervisor, Jakarta : PT Raja Grafindo Persada, 2004.

Hadi, Sutrisno, Metodologi Research, Jilid II, Yogyakarta : Andi Ofset. Hamalik, Oemar, Psikologi Manajemen Penuntun bagi Pemimpin, Bandung : Trigenda Karya, 1993.

Hasibuan, Malayu S.P., Manajemen Sumber Daya Manusia, Jakarta : Bumi Aksara, 2006.

Husaini, Usman, Manajemen Teori Praktek dan Riset Pendidikan, Jakarta : Bumi Aksara, 2008. 
Mangkunegara, Anwar Prabu, Manajemen Sumber Daya Manusia Perusahaan, Bandung: PT Remaja Rosdakarya, 2009.

Mulyasa, Uji Kompetensi dan Penilaian Kinerja Guru 2013, Bandung: Remaja Rosda Karya, 2013.

Nawawi, Hadari, Majemen Sumber Daya Manusia untuk Bisnis yang Kompetitif, Yogyakarta : Gajah Mada University Press, 2011.

Prastowo, Andi, Memahami Metode- Metode Penelitian, Yogyakarta : Ar- Ruzz Media, 2011.

Schermerharn, Manajemen, Yogyakarta: Penerbit Andi, 2003.

Sinambela, Lijan Poltak, Kinerja Pegawai (Teori, Pengukuran dan Implikasi), Yogyakarta: Graha Ilmu, 2012.

Singarimbun, Masri, Metode Penelitian Survey, Yogyakarta : LP3S, 1989

Sudarmanto, Kinerja dan Pengembangan Kompetensi SDM (Teori, Dimensi Pengukuran, dan Implementasi Dalam Organisasi), Yogyakarta : Pustaka Pelajar, 2009.

Sugiyono, Metode Penelitian Kuantitatif, Kualitatif, dan R\&D, Bandung: Alfabeta, 2008.

Sutrisno, Edy, Manajemen Sumber Daya Manusia, Jakarta: Prenada Media Group, 2009.

Undang-Undang Republik Indonesia No. 14 Tahun 2005. pasal 20 tentang Guru dan Dosen 